\title{
PRECLINICAL STUDENTS' VIEWS ON MEDICAL ETHICS EDUCATION: A FOCUS GROUP STUDY IN TURKEY
}

\author{
Ahmet Can Bilgin¹, Sevgi Timbil², Cemal Huseyin Guvercin, Sema Ozan², Semih Semin ${ }^{1}$
}

\begin{abstract}
Aim: We aimed to receive the opinions of the preclinical medical students on medical ethics education, and to present some suggestions for the education program. Methods: Focus group discussions were held with third-grade medical students. The analyses were implemented using Creswell's six-step qualitative data analysis. Results: During the data analysis, themes with the following titles were identified: necessity of the education, content, education methods, assessment, participation, contribution of the education, moving to clinical training and suggestions. Discussion: The students stated that the discussions on movies/ books/case-based scenarios are more useful than lectures. Although they believed that student assessment was necessary for the medical ethics education, they had negative attitudes towards Multiple Choice Questions. At the stage of moving to the clinical training, their feelings and thoughts about the learning outcomes they would gain from ethical education were contradictory. Conclusion: Each theme and code obtained from the students' expressions may contribute to improving medical ethics education for all institutions. Besides student education, it is also necessary the faculty development programs on medical ethics education for clinical teachers. Additionally, further studies can be conducted on the actions that need to be taken to help students internalize the ethical issues and feel the need of learning more.
\end{abstract}

Key words: medical ethics, education, focus group, medical schools

Puntos de vista de estudiantes de pre-clínica sobre educación en ética médica: un estudio de grupo focal en Turquía

Resumen: Nuestro objetivo consistió en recibir las opiniones de estudiantes de medicina en pre-clínica sobre educación en ética médica y presentar algunas sugerencias para el programa de educación. Métodos: Se mantuvo discusiones de grupo focal con estudiantes de medicina de tercer grado. Se implementó el análisis cualitativo de datos de seis pasos de Creswell. Resultados: Mediante el análisis de datos, se identificaron los siguientes temas: necesidad de la educación, contenido, métodos de educación, evaluación, participación, contribución de la educación, el paso a formación clínica y sugerencias. Discusión: Los estudiantes consideraron que las discusiones sobre películas/libros/escenarios de casos eran más útiles que las clases dictadas. Aunque pensaban que la evaluación de los estudiantes era necesaria para la educación en ética médica, no valoraron positivamente las pruebas de preguntas con respuesta múltiple. En el paso a la formación clínica, sus sentimientos y pensamientos sobre los resultados del aprendizaje en educación ética eran contradictorios. Conclusión: Cada tema y código obtenido de las propuestas de los estudiantes puede contribuir a mejorar la educación en ética médica en las instituciones. Además de la educación, también es necesario desarrollar programas sobre educación ética médica para los profesores clínicos. Además, se pueden realizar más estudios sobre las acciones que se necesitan tomar para ayudar a los estudiantes a internalizar los temas éticos y sentir la necesidad de aprender más.

Palabras clave: ética médica, educación, grupo focal, escuelas de medicina

A perspectiva dos estudantes pré-clínicos sobre o ensino da ética médica: um estudo de grupo focal na Turquia

Resumo: Objetivo: Coletar as opinióes dos estudantes pré-clínicos de medicina no ensino da ética médica e apresentar algumas sugestóes para o programa de ensino. Métodos: foram realizadas discussōes em grupos focais com estudantes do $3^{\circ}$ período de medicina. As análises foram implementadas usando o método qualitativo de seis etapas de Creswell. Resultados: Durante a análise de dados, os seguintes temas foram identificados: a necessidade da educação, conteúdo, métodos de ensino, avaliação, participação, contribuição da educação, transição para o treinamento clínico e sugestôes. Discussão: Os alunos concluíram que as discussóes sobre filmes/livros/estudos de caso são mais úteis que aulas expositivas. Embora eles acreditassem que a avaliação de alunos era necessária para o ensino da ética médica, eles tinham atitudes negativas em relaçáo a questóes de múltipla escolha. $\mathrm{Na}$ fase de transição para o treinamento clínico, seus sentimentos e pensamentos sobre os resultados da aprendizagem, que eles obteriam com o ensino da ética eram contraditórios. Conclusão: Cada tema e código obtidos das opiniōes dos alunos podem contribuir para melhorar o ensino da ética médica para todas as instituiçóes. Além do ensino dirigido ao aluno, é necessário que haja também programas de desenvolvimento do corpo docente acerca da educação de ética médica. Ademais, mais estudos podem ser realizados sobre as açóes que precisam ser tomadas para ajudar os alunos a interiorizar as questóes éticas e sentir a necessidade de aprender mais a respeito.

Palavras-chave: ética médica, educação, grupo focal, faculdade de medicina

\footnotetext{
${ }^{1}$ Dokuz Eylul University, Faculty of Medicine, Department of History of Medicine and Ethics, Izmir, Turkey

${ }^{2}$ Dokuz Eylul University, Faculty of Medicine, Department of Medical Education, Izmir, Turkey

${ }^{3}$ Dokuz Eylul University, Faculty of Medicine, Department of History of Medicine and Ethics, Izmir, Turkey. Division of Developmental Medicine, Boston Children's Hospital, Harvard Medical School, Boston, Massachusetts, USA

Correspondence: cemalcin@yahoo.com
} 


\section{Introduction}

Medical ethics and human rights are the topics that are commonly incorporated in the medical education curriculums around the world. In addition to the World Medical Association's recommendation, the World Health Organization's statement emphasizing the necessity of helping medical students attain knowledge, skills and attitudes that will be necessary in their occupational life is an important proof of such common feature of this practice $(1,2)$. National and international institutions for the accreditation of medical schools also point out the necessity of incorporating ethical elements into the medical education curriculums(3-5). In line with these recommendations, the medical students in most of the medical schools in Turkey are provided with medical ethics education in the term prior to their graduation.

Although the scope of the medical ethics education provided in different faculties differs, there is a consensus on main objectives(6). There are various methods used in medical ethics education such as lectures, observations, case methods, practicals, small group studies, role plays, Problem Based Learning (PBL) etc. Although there is no consensus on how effective medical ethics education should be $(7,8)$, it is accepted that medical ethics education should be integrated into curricula from the beginning of medical education, continued throughout the whole education process and a true correlation in clinical practice experience(9-11).

Assessment of the students is also required in medical ethics education, just like in other fields of medicine $(12,13)$. Proper assessment of students should be performed in a way to ensure efficiency of ethics education and to help students recognize the humanitarian aspect of medicine and gain necessary skills to analyze ethical dilemmas in clinical practice(14). Objective Structured Clinical Examination (OSCE), observations, portfolios, self and peer assessments, written assessments, standardized patients etc. are some of the methods used for the assessment of students $(15,16)$.

Dokuz Eylul University Faculty of Medicine (DEUFM), is the first accredited faculty of medicine in Turkey by national accreditation system
Association for Evaluation and Accreditation of Medical Education Programs (TEPDAD) that recognized by World Federation for Medical Education. Also, it is one of the first faculties to implement the active education (PBL, TBL) system. Undergraduate medical education in DEUFM lasts six years(17). PBL is applied in the first three years, while the Task Based Learning method is adopted in the fourth and fifth grades. The final year involves internship(18). Medical ethics education has been offered since the 1980s. It is included in the curriculum throughout six years, but is more intensive in the first three years. There are various activities used to teach the objectives of medical ethics to students such as interactive lectures, problem-based learning sessions, discussions on cases and current media news, discussions and writing assignments on books/ethical issues/movies. Theoretical exams are held in the form of Multiple Choice Questions (MCQs). Besides, assignments for writing book, ethical issue and movie reviews are given during the first three years, respectively. Students are required to attend the discussion session held for each assignment topic in company with an instructor at the end of the academic year. Students are assessed using an assessment form at the end of each clinical clerkship period in $4^{\text {th }}$ and $5^{\text {th }}$ grades in terms of having the attitude and skills consistent with ethical principles and professional role of a physician (Appendix 1). The medical ethics education is usually provided by the instructors from the Department of History of Medicine and Ethics. In addition, instructors from different fields such as public health, medical education and forensic medicine also provide assistance in carrying out these trainings.

Students' and instructors' feedback and the studies on medical ethics education are used to assess the medical ethics education programs $(19,20)$. Receiving opinions of students is a recommended and commonly used approach in scientific research and the evaluation of education programs $(11,21-23)$. From this point of view, this study aims to reveal medical students' views on the medical ethics education provided in the first three grades prior to clinical training, and to present some suggestions for the education program. 
Appendix 1: The topics, teaching and assessment methods of the DEUFM medical ethics program*

\begin{tabular}{|c|c|c|c|}
\hline & Topics & Teaching methods & Assessment methods \\
\hline $\begin{array}{l}\text { First } \\
\text { Year }\end{array}$ & $\begin{array}{l}\text { Introduction to the medical ethics } \\
\text { History of medicine } \\
\text { The role of physician throughout the } \\
\text { history } \\
\text { The medical profession and human rights } \\
\text { Patient rights } \\
\text { Healthcare and environmental rights } \\
\text { The healthcare and law } \\
\text { The ethical responsibility of the physician } \\
\text { in the administration of medicine } \\
\text { Ethical issues in scientific research } \\
\text { Contemporary ethical problems }\end{array}$ & $\begin{array}{l}\text { Interactive lectures, } \\
\text { PBL }^{* *} \text { scenarios, } \\
\text { SGD }{ }^{* * *} \text { on book } \\
\text { assignments }\end{array}$ & $\begin{array}{l}\text { MCQs in end-block } \\
\text { exams } \\
\text { to join to SGD on the } \\
\text { book assignments } \\
\text { Report on book } \\
\text { assignment }\end{array}$ \\
\hline $\begin{array}{l}S \text { e c o n d } \\
\text { Year }\end{array}$ & $\begin{array}{l}\text { Family planning and ethics } \\
\text { Genetics and ethics } \\
\text { AIDS and ethics } \\
\text { Birth and death in the history of medicine } \\
\text { The patient-physician relationship } \\
\text { throughout the history } \\
\text { Social and legal rights of disabled } \\
\text { individuals }\end{array}$ & $\begin{array}{l}\text { Interactive lectures, } \\
\text { PBL scenarios, } \\
\text { SGD on case-based } \\
\text { ethical issues, } \\
\text { SGD on ethical issue } \\
\text { assignments }\end{array}$ & $\begin{array}{l}\text { MCQs in end-block } \\
\text { exams } \\
\text { to join the discussions } \\
\text { on ethical issue } \\
\text { assignments } \\
\text { Report on ethical issue } \\
\text { assignments }\end{array}$ \\
\hline $\begin{array}{l}\text { Third } \\
\text { Year }\end{array}$ & $\begin{array}{l}\text { Responsibilities of the physician } \\
\text { Ethics and disaster medicine } \\
\text { Ethical issues discussion }\end{array}$ & $\begin{array}{l}\text { Interactive lectures, } \\
\text { PBL scenarios, } \\
\text { SGD on case-based } \\
\text { ethical issues, } \\
\text { SGD on movie } \\
\text { assignments }\end{array}$ & $\begin{array}{l}\text { MCQs in end-block } \\
\text { exams } \\
\text { to join SGD on the } \\
\text { movie assignments } \\
\text { Report on movie } \\
\text { assignments }\end{array}$ \\
\hline $\begin{array}{l}\text { Cli n i c a } 1 \\
\text { Years } \\
(4 \mathrm{th}-5 \mathrm{th})\end{array}$ & $\begin{array}{l}\text { Within the scope of the elective clerkship } \\
\text { In addition: Discussion sessions to enable } \\
\text { students to consider the ethical dimension } \\
\text { during their tasks in clinical years }\end{array}$ & Discussion sessions & $\begin{array}{l}\text { As an element in } \\
\text { the end-task process } \\
\text { assessment form }\end{array}$ \\
\hline $\begin{array}{l}\text { Internship } \\
\text { (6th year) }\end{array}$ & $\begin{array}{l}\text { A discussion session on the ethical and } \\
\text { legal problems experienced in primary } \\
\text { healthcare services } \\
\text { A 2-hour case discussion on a case } \\
\text { experienced by students }\end{array}$ & $\begin{array}{l}\text { Interactive group } \\
\text { study within the scope } \\
\text { of the public health } \\
\text { internship }\end{array}$ & \\
\hline
\end{tabular}




\section{Method}

For the purpose of the study, a qualitative research method was adopted and focus group interviews were held to find out the students' views in detail. Focus group interviews are advantageous compared to one to one interviews in terms of clarifying questions, receiving more extensive and in-depth opinions by means of interactions among the participants and seeking answers to the questions like "why?", "how?" and "what?" (24-26). They are also used for program evaluations(27). The students were chosen through the Purposive Sampling Method to be involved in the focus group sessions. The sampled population consisted of third-grade students who had completed ethics education, but not yet begun clinical practice. The sample consisted of 18 students joined from among 21 volunteers. It was formed by considering the male to female ratio.

For each focus group interview, 7 or 8 students were invited. Three focus group interviews were held within the same week in an isolated room. The interviews were steered by two moderators (authors of this study) trained in conducting focus group interviews. The first moderator asked the questions, while the second moderator performed the technical follow-up of the recording process and took notes by observing the interview process(28).

The moderators were not involved in the medical ethics education and assessment of the students attending the interviews. At the beginning of the interviews, the students were provided with information about the focus group meeting and the aim of this study. They were also informed that the interviews would be recorded and their names would not be mentioned. Their signed informed consent was obtained. A code name was assigned to each student and these names were used while transcribing the records.

Some open-ended questions were asked by the researchers to the students to make them express in detail their opinions on the medical ethics education provided during the first three years of medical education. These questions were classified under 4 main titles:
- What do you think about the incorporation of ethics education into the medical education curriculum?

Regarding the medical ethics education provided to this date:

- What do you think about the education activities and methods?

- What do you think about the participation of students in education activities?

- What do you think about the assessment of students' learning in medical ethics and the assessment methods?

Regarding the learning outcomes of medical ethics education and the aspects of this education that need to be improved:

- What do you think are the positive aspects of medical ethics education?

- Did medical ethics education lead to any change in your opinions or behaviors? If so, please explain and give examples?

- What do you think are the aspects of medical ethics education that need to be improved?

- How do you feel about dealing with ethical problems during this term in which you are about to move forward to clinical training?

The data collection was completed following the third focus group interview due to repetitions and the inability to collect new and different information upon considering that saturation point has been $\operatorname{reached}(28,29)$.

Data Analysis: Creswell's six-step qualitative data analysis process and interpretation was used for the analysis of data(30). Immediately after the interviews, they were transcribed verbatim by two researchers. All interviews are tabulated by indicating the code names of the students, the number of focus group interviews, interview questions, observer's notes etc. In this way, the data was organized for the analysis. Data analysis was performed independently by hand by the same two researchers. The transcribed text prepared 
for analysis was re-read a couple of times. During this process, repetitive words, sentences and phrases meaningful for the purpose of the study were searched and codes were defined. Then, the themes (categories) were developed using the codes thought to be linked with each other. Two researchers compared their codes and themes and modified them into their final form. The codes and themes were shared with the other researchers and assessed together. The findings were interpreted and reported in the light of the literature review. Direct quotations of some of the participants were used to support the findings(29). In the discussion section, findings obtained from the focus group interviews were discussed based on the literature review using expressions like "sometimes", "often", "mostly" etc.(29).

Ethical approval was obtained from the Ethics Committee of DEUFM.

\section{Findings}

Three focus group interviews were held and a total of 18 students ( 8 female and 10 male) participated in the interviews. The groups consisted of 7, 5 and 6 students, respectively. The average age of students was 22.5 years (min: 20 - max: 25). The average interview time was approximately 72 minutes. The interviews were completed in May 2013. At the end of the qualitative data analysis, eight themes were identified. Table 1 shows the themes and the codes under the themes. The statements under the theme "suggestions" were assessed and organized as codes, and they were presented in a different table since they included long statements (Table 2).
Table 1. Themes and codes identified at the end of the qualitative data analysis

\begin{tabular}{|c|c|}
\hline Themes & Codes \\
\hline $\begin{array}{l}\text { Necessity of the } \\
\text { Education }\end{array}$ & $\begin{array}{l}\text { Necessary } \\
\text { Reason } \\
\text { Late }\end{array}$ \\
\hline Content & $\begin{array}{l}\text { Hippocrates' Four } \\
\text { Temperaments } \\
\text { Being human } \\
\text { Professional confidence } \\
\text { Abortion } \\
\text { Triage } \\
\text { Forensic case } \\
\text { Euthanasia } \\
\text { Malpractice } \\
\text { Obtaining informed } \\
\text { consent } \\
\text { Organ mafia } \\
\text { Organ donation } \\
\text { Articles } 280 \text { and } 279 \\
\text { of Turkish Penal Code } \\
\text { (Failure by the Public } \\
\text { Officer and the Medical } \\
\text { Professionals to Report } \\
\text { an Offence) } \\
\text { Conflict between laws } \\
\text { and ethical principles } \\
\text { Fabrication in Scientific } \\
\text { Research } \\
\text { Plagiarism } \\
\text { Putting yourself in } \\
\text { someone else's place } \\
\text { Notifiable Diseases } \\
\text { Death } \\
\text { Experiments on the Jews }\end{array}$ \\
\hline Education Methods & $\begin{array}{l}\text { Lectures } \\
\text { Practicals } \\
\text { Assignments (ethical } \\
\text { issue, movie, book) }\end{array}$ \\
\hline Assessment & $\begin{array}{l}\text { Necessary } \\
\text { Method }\end{array}$ \\
\hline Participation & $\begin{array}{l}\text { Difference from the other } \\
\text { courses } \\
\text { Obligation }\end{array}$ \\
\hline $\begin{array}{l}\text { Contribution/effect of the } \\
\text { education }\end{array}$ & $\begin{array}{l}\text { Difference } \\
\text { Point of view } \\
\text { Confusion }\end{array}$ \\
\hline $\begin{array}{l}\text { Moving to Clinical } \\
\text { Training }\end{array}$ & $\begin{array}{l}\text { Teachers } \\
\text { Healthcare System } \\
\text { Awareness }\end{array}$ \\
\hline
\end{tabular}


Table 2. Statements/Codes under the theme $\mathrm{Su}$ ggestions.

Education activities should be focused on making
students think instead of guiding them
Focus should be shifted from the first grade to the third
grade which is closer to clinical training-
Weekly movie/discussion and reading/discussion sessions
open to voluntary participation
Sessions to be held to discuss current ethical issues on
certain times at the lecture hall based on voluntary
participation
More practical than lectures
Opportunity to discuss different points of view
Sharing the previous week's ethical issues on Mondays
and discussing them on Fridays. Awarding bonus points
for participating in this activity
Planning discussions at the lecture hall in the format of
a moot
Planning observations at hospitals, family healthcare
centers etc. Socializing with patients
Integrated activities that will integrate medical ethics
with the field of medicine
More movie discussions instead of just one organized at
the end of the year
Interpreting the assignments and providing students with
feedback
Opportunity of more practical
Planning practical intended to cause behavioral changes
Opportunity to put the knowledge given in the lectures
into practice
Giving movie and reading assignments twice a year
Conveying the importance of ethics to students somehow
Awarding bonus points in the assessments
Asking case-based questions in the exams
Using the reward method by giving bonus points to the
assignments
Activities allowing for discussion and helping individuals
convey their thoughts

\section{Discussion}

This study aimed to evaluate to the medical ethics education provided prior to clinical training through the perspectives of the students, as well as offering suggestions for the curriculum as a whole. Students' willingness to express their opinions during the focus group interviews, their active participation by means of referring to each other and the lack of students trying to be dominant in the group all ensured the collection of a wide range of data. This section presents the discussion of the findings in the light of the literature and the themes obtained from the analysis of focus group interviews.
Necessity of the Education: National and international organizations and the scientific studies based on students' perspectives all provide a strong basis for the necessity of medical ethics education. Studies conducted with the participation of medical students in $\operatorname{Iraq}(21)$, the UK(14), India(31) and Singapore(32) reported that students agreed with the necessity of medical ethics education. In also this study, almost all of the students agreed on the necessity of ethics education (Code: necessity).

Students usually expressed their opinions on the necessity of ethics education giving reasons for their opinions (Code: reason). The most frequently expressed reason was that medicine was a discipline dealing with humans and human healthcare. The other remarkable expressions were as follows: "It steers the profession", "It is a course that will contribute to how we will behave when we encounter problems, how we decide and our ability to judge as well as leading us to thinking", "learning the ethical responsibility of physicians beforehand", "It is necessary, just like other biology-related courses". The reasons expressed by the students indicate that they are aware of the necessity of ethics education. Physicians are expected to know ethical, legal and moral obligations of their practice and to act accordingly(31). In a study conducted with nurses, it was found that having ethical education positively contributes to ethical sensitivity(33).

A few students $(n=4)$ stated that it would be late to provide this education in the university years and individuals' ethical approach is shaped long before, thus this education should be provided much earlier, during elementary school and even in the family environment (Code: late).

Content: The students usually gave examples of ethical issues while delivering their opinion, although they were not directly asked to do so. These examples, each of which was assessed as a code, sort of emphasized the objectives of the medical ethics curriculum of the faculty. It was remarkable to see that the students gave examples of various issues, used expressions about the content and had a solid grasp of the issue, although they are in the third grade and have not been involved in clinical practice much. 
Education Methods: The students had much need to express their opinions on the methods used in ethics education. The following codes were identified under this theme: lectures, practicals and assignments.

Lectures: The students expressed contradictory opinions on lectures. They indicated that they did not attend lectures much, but when they attended, they found them efficient. Cannaerts et al. also reported a similar contradictory approach(34). They indicated that students regarded ethics lectures as dull, not motivating, and not practicable. The same study also reported that these lectures were considered to be informative in terms of basic ethical principles and necessary before the clinical practice. In Saied's study (2013), lectures were listed among the least preferred learning methods in medical ethics education(21). Besides, Aldughaither et al. also reported that students were not in favor of didactic lectures(35). In this study, another remarkable finding on lectures was that students associated them with assessment and considered them as an easy way of getting a grade.

Practicals: The activities within the scope of practical are those educational activities in which small groups of students discuss case-based scenarios, book and movie assignments under the moderation of an instructor. Similar to other studies, in this study, the practicals in medical ethics education were found to be more efficient by the students. The most frequently mentioned reasons why they were found more efficient were as follows: they have high attendance rate; they provide the opportunity of interaction; they can be easily remembered and they make more contribution. Studies reported that group discussions on cases were educationally valuable and they improved students' ability to learn and discuss ethical issues(36). Similarly, Aldughaither et al. revealed that students found interactive teaching methods and discussions on ethical dilemmas experienced by them more interesting (35). In the study by Lehrmann et al., group discussion was found to be the most preferred method by the students in the preclinical ethical training(37).

Assignments: Students expressed contradictory opinions on assignments. Although they were against compulsory assignments and found it difficult to write a report on them, they thought the assignments were beneficial for their learning. They found it more useful to discuss the assigned movies or books in small groups in company with the instructor. As an alternative to compulsory assignments, one of the students recommended, "those submitting their assignments should be awarded bonus points". We observed that movies were preferred over reading assignments, and reading assignments were preferred over writing papers related with ethical issues. It is quite understandable why students think that way. There are studies showing the positive impacts of using movies in teaching. Movies provide various advantages such as showing the ways of dealing with difficult situations, giving examples of different doctor-patient interactions, helping students confront their own emotions and reflect on their learning and revealing different opinions and discussing them etc. (38,39).

Assessment: The most frequently cited issue during the focus group interviews was the assessment. Just like all other subjects in medical education, medical ethics also needs to be assessed $(12,40)$. The students' opinions were also in favor of such assessment (Code: necessity). They believed that the lack of assessment would curb students' interest in the course, thus medical ethics must be assessed just like other courses. A study conducted with first grade medical students found that $82 \%$ of students did not find assessment necessary, while $\% 40$ of sixth graders of the same faculty stated that the assessment of medical ethics education was necessary $(20,41)$.

Most of students thought that it would be more appropriate and useful for the assessment to be done in terms of assignments and qualification or awarded bonus points (Code: method). However, they were against the use of factual knowledge questions and MCQs that require memorization. They stated that such questions would not assess medical ethics and could be answered with a little study. They also stated that correct answers do not mean behaving ethically in real life. Johnston and Haughton also reported that students showed a strong preference for assessment through rolling case studies with short-written answers(14).

In this study, the students who are in the midd- 
le of their education believed in the necessity of assessment in medical ethics education and made some recommendations in this regard, that was found as positive by us.

Contribution/Effect of the Education: The codes under this theme make us believe that students both benefited from the medical ethics education and were experiencing suspense due to being in the half of their education. Under the code $d i-$ fference, there are examples revealing that getting ethics education provides significant knowledge and awareness compared to not receiving any. The examples under the code point of view show that the students have not still experienced any behavioral change, but there are significant differences in their points of view. It is evident that the awareness and knowledge of medical ethics and the skills to define and discuss ethical problems that students have gained to this stage need to be further improved in a more practice-based environment during the clinical training(11).

Under the code confusion, there are examples indicating that some controversial issues and/or contradictions between legal and ethical approaches create confusion. Similar to the findings of this study, some studies reported that increasing awareness also created uncertainty in the minds $(42,43)$. Ethics education was also found to improve ethical perception and reflective and analytical skills of nursing students and to help them become aware of their values and limitations, although its contribution to behavioral change was found to be limited(34).

Participation in Education Activities: All students agreed that participation in ethics lectures is at a low level. As a consequence, students do not attach importance to medical ethics courses as much as they do to the other biology-related courses, and they think they can answer the exam questions by studying the presentations they will obtain from the learning materials center (Code: difference from the other courses). Similarly, studies reported that students usually regard medical ethics as soft science or consider it as a "marginal" and "fluffy" topic $(35,44)$. Saied's study reported that almost half of the students were attending the medical ethics lectures a few times, while one third never attended or attended only occasiona- lly(21). Similarly, in a study conducted in the UK, it has been stated that the ethical issues were less important than other courses according to medical students(8). How to change this negative perspective on medical ethics should be considered as an important issue.

The other code obligation under this theme was affecting the students in two ways. The lack of roll call in courses was one of the reasons for not to participate in the courses. Compulsory attendance in the practicals was a factor in high level of attendance in the practicals. One of the students stated, "... if we attend the course, it is very effective, but students do not, they do not feel that they should attend the ethics course. The common thinking is that it is compulsory, so I should attend. During the practicals and small group activities, discussions necessarily take place and if the topic is interesting, then all students participate and speak up. Even those attending involuntarily participate in the discussions". This statement stands as a good example of the contradictory relationship between obligation and active participation in education activities. It was important to see that students made interpretations and self-criticism while they expressed their opinions on the low level of participation in all medical ethics education activities.

Suggestions: Each of the codes under this theme can be expressed by sentences. It can be considered that these codes offer suggestions for improving medical ethics education which is one of the aims of this study. Students are able to offer various and useful suggestions when they are given the opportunity. According to adult learning principles, we should trust them that they will express their needs in the best way possible. Some other studies also reported that students suggested the use of group studies involving case discussions, clinically integrated activities, role plays(21), clinical visits, interaction with patients and conferences with case discussions(45).

Moving to Clinical Training: The students exhibited contradictory emotions and thoughts under this theme. They believed that learning outcomes of the medical ethics education helped them develop awareness, although they were not sufficient to help them overcome ethical dilemmas (Code: awareness; example of statement: "... we raise a cer- 
tain level of consciousness and develop awareness").

They thought that they had achieved some learning outcomes throughout the first three years, but their behaviors would be affected by those of their clinical teachers to a great extent during the clinical training (Code: teachers; example of statement: "our ethical behaviors will most likely be related to the behaviors of our clinical teachers towards us. Because, the more ethically the teachers behave, but surely their behaviors will affect us.".

Besides, they emphasized that involvement in practice, together with the healthcare system, would be more indicative of their behaviors (Code: healthcare system; example of statement: "...I do not have any power of sanction, I am just a tiny gear in this system.....".)

Contradictory expressions of the students may not be groundless at all. There are studies revealing the importance of role models in ethics education(35) and showing that students had reduced ability to recognize and manage ethical dilemmas during the undergraduate medical education(46). In a recent UK study, it is emphasized that the guidance or training provided to support the role of clinician teachers in ethical education is inadequate(8). Numminen et al. also emphasized that nursing students questioned the applicability of nursing codes of ethics in real-life due to the difference they perceived between theoretical education and nursing practice(47). In this study, the students' expressions are contradictory; however, it should not be forgotten that they have still not completed their education. On the other hand, suspicions about whether medical ethics education guarantees ethical behaviors in clinical practice stand as an important problem for both the faculty and the general medical education(48).

\section{Limitation}

The low number of focus groups interviews may be considered as a limitation; however, it is within the recommended range used for such studies. There is no certain number of interviews advised for such studies to collect information. Barbour suggests that 3 or 4 focus group interviews are sufficient for data collection(28). Repetitions and the inability to collect new and different in- formation upon reaching the saturation point can be indicative of determining the number of focus group sessions(29). In the literature, there are studies in which 2 to 4 focus group sessions were held $(26,49-52)$.

Another limitation may be that one of the groups had 5 students; however, there are different approaches to the number of participants in focus group sessions(28). A minimum of 3 to 4 participants can be sufficient, or 6 to 10 participants can be advised. We believe that the number of students in the groups was appropriate in ensuring that all students could follow and hear each other, actively participate and express different opinions.

\section{Conclusion}

We believe that each code obtained from the students' expressions and placed under the theme suggestions can be considered as suggestions for the medical ethics education provided by all institutions as well as by our faculty.

Students emphasize clinical teachers as a role model; therefore, it is considered that the faculty development programs which include the importance, aim and methods of medical ethics education etc. are also necessary for clinical teachers.

It seems that students have problems with participation and engagement in ethical education activities. Therefore, further studies can be conducted on the actions that need to be taken to help students internalize the ethical issues and feel the need of learning more.

Although the efforts exerted for the ethics education make a contribution to some extent, the outcomes achieved by the students and their ability to behave ethically do not seem to be dependent only on the medical instructors and the medical education. It is evident that the periods before and after the undergraduate medical education is also important. However, the individual patterns that they have brought before medical education and the impact of the health system in which they will practice their profession are also the issues that deserve to be studied more extensively.

The authors declare no conflict of interest. 
Preclinical Students' Views on Medical Ethics Education: A Focus Group Study in Turkey - Ahmet Can Bilgin et al.

\section{References}

1. Peeling RW, Saxena A. Medical Ethics Manual. Bulletin of the World Health Organization 2006; 84(2): 159-160. Cited April 17, 2014. Available from: http://www.who.int/bulletin/volumes/84/2/159.pdf

2. WHO, Regional Office for South-East Asia. Module for teaching medical ethics to undergraduates. 2009. Cited April 20, 2014. Available from: http://apps.searo.who.int/PDS_DOCS/B4401.pdf?ua=1

3. National Standards in Undergraduate Medical Education, 2014. Cited June 10, 2014. Available from: https://uteak.org. tr/uploads/belge/MOTE_STANDARTLAR_2014.pdf

4. American Association of Medical Colleges. Liasion Committee on Medical Education. 2013. Cited 2015 May 13. Available from: http://www.lcme.org/

5. Committee on Accreditation of Canadian Medical Schools. CACMS Standards and Elements. August 2015. Cited June 06, 2017. Available from: https://cacms-cafmc.ca/sites/default/files/documents/CACMS_Standards_and_Elements_-_ AY_2016-17.pdf

6. Miles SH, Lane LW, Bickel J, et al. Medical ethics education: Coming of age. Academic Medicine 1989; 64: 705-714.

7. Schonfeld T, Johnson K, Seville E, et al. Qualitative Differences between Two Methods of Ethics Education: Focus Group Results. Ethics and Social Welfare 2015; 9(3): 240-254.

8. Brooks L, Bell D. Teaching, learning and assessment of medical ethics at the UK medical schools. Journal of Medical Ethics 2016:1-7-

9. Eckles RE, Meslin EM, Gaffney M, et al. Medical ethics education: Where are we? Where should we be going? A review. Academic Medicine 2005; 80: 1143-1152.

10. Louhiala P. Philosophy for medical students-why, what, and how. Journal of Medical Ethics; Medical Humanities 2003; 29: 87-88.

11. Obando FS, Amado ED. Ethics training of medical students: The gap between the formal curriculum and the hidden curriculum. Acta Bioethica 2007, 13(1): 107-113.

12. Boon K, Turner J. Ethical and professional conduct of medical students: review of current assessment measures and controversies. Journal of Medical Ethics 2004; 30: 221-226.

13. Wong J, Cheung E. Ethics assessment in medical students. Medical Teacher 2003; 25(1): 5-8.

14. Johnston C, Haughton P. Medical students' perception of their ethics teaching. Journal of Medical Ethics 2007; 33(7): 418-422.

15. Shumway JM, Harden RM. AMEE Guide No. 25: The assessment of learning outcomes for the competent and reflective physician. Medical Teacher 2003; 25(6): 569-584.

16. Singer PA, Robb AK. The Ethics OSCE: Standardized patient scenarios for teaching and evaluating bioethics. University of Toronto: EFPO 1994. Cited February 01, 2016. Available from: http://wings.buffalo.edu/faculty/research/ bioethics/osce.html

17. The Association for Evaluation and Accreditation of Medical Education Programs, Turkey. WFME, Copenhagen, 8 October 2013. Cited July 01, 2017. Available from: http://uteak.org.tr/uploads/wfme_1.pdf

18. Musal B. Problem-Based Learning \& Task-Based Learning Curriculum Revision Experience of a Turkish Medical Faculty. Creative Education 2013; 4(12): 116-119.

19. Musal B, Taskiran C, Gursel Y, et al. An example of program evaluation project in undergraduate medical education. Education for Health 2008; 21(1): 113.

20. Ozan S, Timbil S, Semin S, et al. Interns' perceptions on medical ethics and ethical issues at the Dokuz Eylul University School of Medicine in Turkey. Education for Health 2010; 23(3): 1-11.

21. Saied NH. Medical students' attitudes to medical ethics education. Annals of the College of Medicine Mosul 2013; 39(2): 101-106.

22. WFME Office. Basic Medical Education WFME Global Standards for Quality Improvement. The 2015 Revision. FerneyVoltaire, France, Copenhagen, Denmark; 2015. Cited May 11, 2016. Available from: http://wfme.org/standards/ bme/78-new-version-2012-quality-improvement-in-basic-medical-education-english/file

23. Nickols F. Evaluating training: There is no "cookbook" approach. 2003. Cited April 03, 2016. Available from: http:// www.nickols.us/evaluating_training.pdf

24. Maeno T, Takayashiki A, Anme T, et al. Japanese students' perception of their learning from an interprofessional education program: a qualitative study. International Journal of Medical Education 2013; 4: 9-17.

25. Kitzinger J. Introducing focus groups. BMJ 1995; 311: 299-302.

26. Aase I, Hansen BS, Aase K. Norwegian nursing and medical students' perception of interprofessional teamwork: a qualitative study. BMC Medical Education 2014; 14: 170. 
27. Steinert Y. Student perceptions of effective small group teaching. Medical Education 2004; 38: 286-293.

28. Stalmeijer RE, Mcnaughton N, Van Mook WN. Using focus groups in medical education research: AMEE Guide No 91. Medical Teacher 2014; 36: 923-939.

29. Wong LP. Focus group discussion: a tool for health and medical research. Singapore Medical Journal 2008; 49 (3): 256.

30. Creswell JW. Educational Research. Planning, Conducting, and Evaluating Quantitative and Qualitative Research. $4^{\mathrm{a}}$. ed. Boston: Pearson; 2012.

31. Selvaraj K, Sivaprakasam P, Nelson BTSB, et al. Perception of interns and postgraduates towards Medical Ethics Education. Internationale Journal of Current Microbiology and Applied Sciences 2013; 2(9): 198-203.

32. Chin JJ, Voo TC, Karim SA, et al. Evaluating the Effects of an Integrated Medical Ethics Curriculum on First-year Students. Annals Academy of Medicine Singapore 2011; 40: 4-18.

33. Ertuğ N, Aktaş D, Faydali S, et al. Ethical sensitivity and related factors of nurses working in the hospital settings. Acta Bioethica 2014; 20(2): 265-270.

34. Cannaerts N, Gastmans C, Casterle BD. Contribution of ethics education to the ethical competence of nursing students: Educators' and students' perceptions. Nursing Ethics 2014; 21(8): 861-878.

35. Aldughaither SK, Almazyiad MA, Alsultan SA, et al. Student perspectives on a course on medical ethics in Saudi Arabia. Journal of Taibah University Medical Sciences 2012; 7(2): 113-117.

36. Smith S, Fryer-Edwards K, Diekema DS, et al. Finding Effective Strategies for Teaching Ethics: A Comparison Trial of Two Interventions. Academic Medicine 2004; 79(3): 265-271.

37. Lehrmann JA, Hoop J, Hammond KG, et al. Medical students' affirmation of ethics education. Academic Psychiatry 2009; 33(6): 470-477.

38. Lumlertgul N, Kijpaisalratana N, Pityaratstian N, et al. Cinemeducation: A pilot student project using movies to help students learn medical professionalism. Medical Teacher 2009; 31(7): 327-332.

39. Ber R, Alroy G. Twenty years of experience using trigger films as a teaching tool. Academic Medicine 2001; 76(6): 656658.

40. Goldie J, Schwartz L, McConnachie A, et al. The impact of three years' ethics teaching, in an integrated medical curriculum, on students' proposed behavior on meeting ethical dilemmas. Medical Education 2002; 36: 489-497.

41. Timbil S, Özan S, Şemin S, et al. Tip fakültesine yeni başlayan öğrencilerin tibbi etik konularina ve eğitimine ilişkin değerlendirmeleri (In English: Incoming Medical Students' Evaluations Regarding Medical Ethics Issues and Medical Ethics Education). Tip Ĕ̈itimi Dünyasi Dergisi 2012; 33: 1-8.

42. Nolan PW, Markert D. Ethical reasoning observed: a longitudinal study of nursing students. Nursing Ethics 2002; 9(3): 243-258.

43. Durgahee T. Reflective practice: nursing ethics through story telling. Nursing Ethics 1997; 4(2): 135-146.

44. Leo T, Eagen K. Professional education, the medical student response. Perspectives in Biology and Medicine 2008; 15(4): 508-516.

45. Roberts LW, Hammond KG, Geppert CM, et al. The positive role of professionalism and ethics training in medical education: A comparison of medical student and resident perspectives. Academic Psychiatry 2004; 28: 170-180.

46. Feudtner C, Christakis D, Christakis N. Do clinical clerks suffer ethical erosion? Students' perceptions of their ethical environment and personal development. Academic Medicine 1994; 69: 670-679.

47. Numminen O, Van der Arend A, Leino-Kilpi H. Nurse educators' and nursing students' perspectives on teaching codes of ethics. Nursing Ethics 2009; 16(1): 69-82.

48. De Zulueta PC. Suffering, compassion and 'doing good medical ethics'. Journal of Medical Ethics 2015; 41: 87-90.

49. Schiekirka S, Reinhardt D, Heim S, et al. Student perceptions of evaluation in undergraduate medical education: A qualitative study from one medical school. BMC Medical Education 2012; 12: 45.

50. Güldal D, Mevsim V, Günvar T, et al. The perspective of peer educators: What are their experiences, feelings, and thoughts? Health 2012; 4(7): 349-356.

51. Özçakar N, Kartal M, Hatipoğlu Ş, et al. A Qualitative Study of Elders' Views on Medicine Usage. Turkish Journal of Geriatrics 2015; 18(3): 205-210.

52. Carlsen B, Glenton C. What about N? A methodological study of sample-size reporting in focus group studies. $B M C$ Medical Research Methodology 2011; 11: 26. 